\title{
Studi Kajian Interaksionisme Simbolik Pondok Pesantren Misbahulkhoir Bojong Purwakarta
}

\author{
Irfan Pernandi ${ }^{1}$ \\ ${ }^{1}$ Program Magister Ilmu Komunikasi, Program Pascasarjana Universitas Pasundan
}

\section{ARTICLE INFO}

\section{Article History:}

Received 05.12.2017

Received in revised form 11.02.2018

Accepted 22.03.2018

Available online

10.04.2018

\begin{abstract}
Salafi boarding school considered as a phenolmena refers to traditional institution of education as an integration of values and culture which contribute to uniqueness tradition and point of view. The uniqueness of salafi boarding school is represented by the symbols and its meaning. The meaning is done by the boarding society, where santri, ustad, and kyai are included, has give us a full meaning of point of view. The meaning as a product of interpretation on symbols to merge in interaction process, and the meaning as the life itself merging in the educational communication pattern of salafi boarding school. The aim of this research are to describe santri, ustad, and kyai understanding on self-concepts, meaning on the symbols as objects, meaning on symbolic activities, and the sharedmeaning between members of salafi society. This research is using Herbert Blumer's Interactionism Symbolic theory with qualitative approach and constructivism method and using Sympathetic Instrospection to analyze. The result of this research is that the self-concept has form the meaning on symbolic objects that include physical and nonphysical objects which is forming in symbolic activities so all of it would perform the shared meaning as a educational communication pattern of salafi boarding school.
\end{abstract}

Keywords:

Boarding School, Interactionism Symbolic, Salafi.

DOI: $10.30653 / 003.201841 .36$

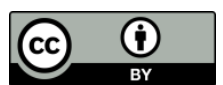

This is an open access article distributed under the terms of the Creative Commons Attribution 4.0 International License, which permits unrestricted use, distribution, and reproduction in any medium, provided the original work is properly cited. @ 2018 Irfan Pernandi.

(c)

\section{PENDAHULUAN}

Proses interaksi dan komunikasi selalu mempertukarkan lambang-lambang simbolik yang syarat dengan muatan makna. Setiap individu akan mempengaruhi dan dipengaruhi individu lainnya. Dengan demikian, tidak ada individu yang bebas nilai dari pengaruh individu lainnya, baik secara personal maupun secara berkelompok. Jadi pemaknaan individu terhadap lingkungannya akan banyak bergantung pada interaksi dan komunikasi individu tersebut dengan lingkungannya yang beraneka ragam menurut intensitasnya masing-masing.

Pondok Pesantren Salafiyah merupakan lingkungan simbolik yang unik dan tersendiri, dimana dalam kegiatan komunikasi pendidikannya melibatkan pemaknaan simbol yang melekat di dalamnya. Hal ini dikarenakan simbol merupakan bagian dari bentuk komunikasi dari warga pontren dimana Kyai, Ustad, dan para santri biasanya menggunakan simbol-simbol dan istilah yang berbeda dengan pondok pesantren lainnya dan biasanya hanya mereka saja yang mengetahui.

${ }^{1}$ Corresponding author's address: Universitas Pasundan, Bandung, Indonesia e-mail: irfan-pernandi@mail.unpas.ac.id 
Sehingga dari cara pandang pendidikan, pemahaman akan makna simbol, penggunaan dan penyampaian simbol-simbol merupakan bagian dari komunikasi pendidikan. Aspek-aspek tersebut inilah yang kemudian diteliti menggunakan teori interaksi simbolik.

Dalam pondok pesantren salafiyah berbagai fenomena dari rutinitas kegiatan, interaksi sosial warga pontren, proses komunikasi, dan kegiatan belajar mengajar merupakan satu kesatuan utuh dari budaya pontren salafiyah yang memberikan cara pandang dan tradisi yang unik dan tersendiri. Satu kesatuan yang utuh ini dalam arti kegiatan keseharian, yang didalamnya terdapat interaksi dan komunikasi, dan kegiatan pertukaran pesan belajar mengajar dalam majlis atau madrasah merupakan bagian utuh dari proses pendidikan pondok pesantren salafiyah, seperti yang diungakapkan sebelumnya, proses pendidikan dalam pontren salafiyah berlangsung tanpa batasan ruang dan waktu. Kapan dan apapun kegiatannya, hal itu merupakan bagian dari pendidikan dan ini merupakan kelebihan dari pondok pesantren salafiyah.

Menurut Herbert Blumer, interaksionis simbolik menunjuk pada sifat khas dari interaksi yang terjalin antar manusia. Manusia dalam interaksi simbolik saling menerjemahkan dan saling mendefinisikan tindakannya. Tanggapan seseorang tidak dibuat secara langsung terhadap tindakan orang lain itu, tetapi didasarkan pada makna yang diberikan terhadap tindakan orang lain. Interaksi antar individu ditandai dengan penggunaan simbol-simbol, interpretasi atau dengan saling memahami maksud dari tindakan masing-masing. Manusia bukanlah suatu proses jika ada stimulus secara otomatis akan langsung menimbulkan tanggapan atau respon. Proses interpertasi setelah terjadinya respon merupakan proses berpikir manusia yang disebut kemampuan khas yang dimiliki manusia. (Blumer, 1969: 34)

Penelitian ini diharapkan dapat mengungkap fenomena ilmiah dan alamiah dari nilai-nilai luhur komunikasi dan pendidikan paripurna dalam pondok pesantren salafiyah melalui cara pandang teori Interaksionisme Simbolik yang diajukan oleh Herbert Blumer, sehingga tradisi salafiyah terangkat kembali sebagai salah satu model komunikasi, pembelajaran, dan pendidikan yang terbarukan kembali di Indonesia.

\section{METODE}

Penelitian ini menggunakan metode kualitatif dengan pendekatan eksplorasi dan inspeksi. Peneliti menggunakan metode penelitiaan kualitatif dengan didasari beberapa hal sebagai berikut: pertama, yang dikaji dalam penelitian ini adalah makna simbol dari suatu tindakan simbolik. Kedua, dalam menghadapi lingkungan sosial, individu memiliki strategi dan pemahaman sendiri terhadap lingkungan simboliknya sehingga memerlukan pengkajian yang lebih mendalam dan penelitian kualitatif memberikan peluang bagi pengkajian mendalam terhadap suatu fenomena. Ketiga, penelitian tentang individu di dalam komunitas atau masyarakat tertentu, dalam hal ini pondok pesantren, sangat memungkinkan digunakannya pendekatan kualitatif, karena yang dikaji adalah fenomena yang tidak bersifat eksternal tetapi berada dalam diri masing-masing individu yang menjadi subyek penelitian. Keempat, penelitian kualitatif memberikan peluang untuk memahami fenomena menurut emic view atau pandangan aktor setempat. Disini peneliti hanyalah orang yang belajar mengenai apa yang menjadi pandangan subjek penelitian, terutama pandangannya terhadap penggunaan simbol-simbol. Kelima, proses interaksi simbolik yang didalamnya terkait dengan makna subyektif harus dipahami dalam kerangka "ungkapan" mereka sendiri, sehingga perlu dikaji dengan kerangka penelitian kualitatif. Keenam, studi interaksionisme simbolik termasuk bagian dari tradisi penelitian kualitatif yang berasumsi bahwa penelitian sistematik harus dilakukan dalam lingkungan yang alamiah.

Interaksi simbolik termasuk bagian dari tradisi penelitian kualitatif yang berasumsi bahwa penelitian sistematik harus dilakukan dalam lingkungan yang alamiah, dengan tujuh prinsip metodologis sebagai berikut:

1) Simbol dan interaksi harus dipadukan sebelum penelitian tuntas.

2) Peneliti harus mengambil perspektif atau peran orang lain yang bertindak (the acting other) dan memandang dunia dari sudut pandang subyek. Namun dalam malakukannya, peneliti harus 
membedakan antara konsepsi realitas kehidupan sehari-hari dengan konsepsi ilmiah mengenai realitas tersebut.

3) Peneliti harus mengaitkan simbol dan definisi subjek dengan hubungan sosial dan kelompokkelompok yang memberikan konsepsi demikian.

4) Setting perilaku dalam interaksi dan pengamatan ilmiah harus dicatat.

5) Metode penelitian harus mampu mencerminkan proses atau perubahan, juga bentuk perilaku yang statis.

6) Pelaksanaan penelitian hendaknya dipandang sebagai suatu tindakan interaksi simbolik.

Dalam analisisnya, untuk mendukung penggunaan konsep-konsep kepekaan yang secara sederhana menyarankan apa yang dicari, ke mana mencarinya, dan tidak terlalu berbuat semenamena pada dunia nyata, peneliti menggunakan pendekatan introspeksi simpatetik (sympathetic introspection) untuk meneliti dunia sosial. Peneliti menempatkan dirinya dalam posisi pelaku, dengan tujuan untuk memahami situasi dari sudut pandang pelaku.

\section{HASIL DAN PEMBAHASAN}

Perspektif interaksionisme simbolik mengandung dasar pemikiran tentang makna subjektif dari perilaku manusia, proses sosial dan pragmatism. Interaksionis simbolik menunjuk pada sifat khas dari interaksi yang terjalin antar manusia. Manusia dalam interaksi simbolik saling menerjemahkan dan saling mendefinisikan tindakannya. Tanggapan seseorang tidak dibuat secara langsung terhadap tindakan orang lain itu, tetapi didasarkan pada makna yang diberikan terhadap tindakan orang lain. Interaksi antar individu ditandai dengan penggunaan simbol-simbol, interpretasi atau dengan saling memahami maksud dari tindakan masing-masing. Manusia bukanlah suatu proses jika ada stimulus secara otomatis akan langsung menimbulkan tanggapan atau respon. Proses interpertasi setelah terjadinya respon merupakan proses berpikir manusia yang disebut kemampuan khas yang dimiliki manusia.

Teori interaksionis simbolik menekakankan pada proses interpretasi yang diberikan oleh individu terhadap stimulus yang datang. Kehidupan masyarakat jika dipandang menurut teori ini adalah individu atau unit-unit tindakan yang terdiri dari sekumpulan orang tertentu yang saling menyesuaikan atau saling mencocokkan interpretasi. Manusia hanya memiliki kapasitas umum untuk berpikir yang harus dibentuk dan diperhalus dalam proses interaksi sosial. Interaksionis simbolik mulai difokuskan pada sosialisasi.

Interpretasi yang dilakukan oleh individu atau unit-unit penindak (actor) dilakukan dengan memaknai dirinya yang membentuk interpretasi terhadap konsep diri, dengan memaknai objekobjek simbolik yang berada di lingkungan yang diinterpretasikan juga sebagai lingkungan simbolik, juga dengan memaknai tindakan-tindakan simbolik yang pada akhirnya menciptakan pemaknaan bersama (shared meaning) yang dipandang sebagai joint action antara aktor yang terlibat didalamnya, dalam hal ini santri, ustad, dan kyai.

\section{Konsep Diri Santri, Ustad, dan Kyai}

Konsep diri sebagai faktor yang menentukan dalam komunikasi antara santri, ustad, dan kyai di pondok pesantren salafiyah Misbakhulkhoir, dimana setiap individu berpikir dan berinteraksi dengan dirinya sendiri. Selanjutnya melakukan proses penilaian (interpretasi) untuk mengetahui untung-rugi, baik-buruk, benar-salah, dari tindakan yang dipilih tersebut, untuk bertingkah laku sesuai dengan apa yang diinginkan dan diharapkan oleh diri yang lain. Berikut ini penjabaran dari konsep diri masing-masing dari santri, ustad, dan kyai yang merupakan cara pandang masingmasing terhadap diri oleh diri sendiri, dan cara pandang diri berdasarkan cara pandang orang lain. Berikut ini penjabaran dari konsep diri masing-masing dari santri, ustad, dan kyai yang merupakan cara pandang masing-masing terhadap diri oleh diri sendiri, dan cara pandang diri berdasarkan cara pandang orang lain.

Konsep Diri Santri Pondok Pesantren Salafiyah Misbahulkhoir

Konsep diri yang terdapat dalam diri (self) santri Misbahulkhoir berkembang pada suatu area dimana peran " $M e$ " lebih besar dan mengalahkan ego "I". Dengan demikian diri (self) santri 
merupakan bentuk definisi kepada kiainya, situasi, objek, dan bahkan kepada diri santri sendiri yang kemudian menentukan tindakannya. Namun, yang perlu digarisbawahi bahwa tindakan diri (self) santri tidak dapat digolongkan sebagai kebutuhan, dorongan, impuls, tuntutan budaya atau tuntutan peran, melainkan tindakan santri hanya didasarkan pada definisi atau penafsiran santri atas objek-objek di sekelilingnya sendiri, sehingga diantara pikiran (mind) dan diri (self) santri menjadi bagian dari interaksi sosial. Santri mendefinisikan dirinya sebagai orang yang sedang belajar agama. Dengan kata lain, santri adalah orang yang memiliki pemahaman agama yang lebih baik daripada orang yang bukan santri. Kemudian tinggal di asrama dengan menjaga dan menjalankan nilai-nilai, norma, etika, dan budaya yang ada di pondok pesantren Misbahulkhoir.Area konsep diri ini terjadi jika seseorang memandang dirinya sendiri tidak hanya sebagai individu utuh, melainkan melibatkan faktor-faktor luar dirinya, sehingga konsep diri santri dijabarkan sebagai berikut:

Pertama, santri mengukur diri terhadap penilaian santri lain, ustad, kyai, dan masyarakat terhadap dirinya, sehingga ada standarisasi diri yang dilakukan oleh santri Misbah.

"Kadang-kadang aya rasa bangga oge sih, Kang, jadi santri didieu teh, maksudna mah sanes sombong, ngan aya rasa syukur, urang sadayana tiasa nyantri di Misbah, nya sigana mah kersaning Gusti Alloh we, ngan tinggal kumaha urang carana ngajalani sapopoe jadi santri anu bener."

“Terkadang ada rasa bangga untuk menjadi santri di Misbahulkhoir, bukan rasa bangga yang mengarah pada kesombongan, tapi rasa bangga karena bersyukur kita semua bisa menjadi santri di Misbah, semua merupakan kasih sayang Alloh SWT, tinggal bagaimana kita menjalani santri dengan benar" (Hasil wawancara dengan informan santri Muhammad Badri Tamam, tanggal 2 februari 2017)

Kedua, santri menyadari dirinya merupakan bagian dari suatu lembaga tata nilai luhur, yakni Pontren Misbahulkhoir, dan dirinya merupakan representasi dari pondok itu sendiri. Baik buruknya penilaian orang lain terhadap pontren Misbahulkhoir ditentukan oleh citra yang dihasilkan dari perilaku para santrinya.

"Karaos ku nyalira, janten santri seueur pisan bentenna sareng jalmi sanes komo di jaman ayeuna mah, ti kawitan cara nyarios teu kenging patos garihal, dina anggoan kedah nganggo nu sae saur agama. Kumargi abdi nyandang 4epr Misbah, pami abdi ditinggalna awon ku nu sanes, Kang Haji sareng ustad-ustad di dieu bakal kacandak awonna."

"Yang dirasakan oleh diri sendiri, jadi santri banyak sekali bedanya dengan orang lain (yang bukan santri) apalagi di zaman sekarang ini, dari mulai cara berbicara yang tidak boleh terlalu kasar, dari pakaian yang harus menggunakan pakaian yang baik menurut agama. Karena saya menyandang nama Misbah, kalau saya dilihat jelek oleh orang lain, maka Kang Haji dan ustad-ustad disini akan terbawa jelek juga." (Hasil wawancara dengan informan santri Ujang Ikhsan, tanggal 3 februari 2017)

Ketiga, mewajibkan diri santri sendiri untuk berkomunikasi sesuai dengan apa yang distandarkan oleh dirinya sendiri, salah satunya yakni cara berpakaian, dimana tuntutan ini berdasarkan tuntunan yang diperoleh dan berlaku juga ketika santri sedang berada diluar pondok.

Keempat, terkandungnya nilai keikhlasan dan penyerahan diri total sebagai seorang santri Misbahulkhoir, dalam artian semua harapan dan tujuan hidup santri dalam pondok termasuk didalamnya hasil pendidikan yang akan diperoleh, semuanya tergantung pada lembaga pontren Misbahulkhoir. 
"Kadang-kadang aya rasa bangga oge sih, Kang, jadi santri didieu the, maksudna mah sanes sombong, ngan aya rasa syukur, urang sadayana tiasa nyantri di Misbah, nya sigana mah kersaning Gusti Alloh we, ngan tinggal kumaha urang carana ngajalani sapopoe jadi santri anu bener."

“Terkadang ada rasa bangga untuk menjadi santri di Misbahulkhoir, bukan rasa bangga yang mengarah pada kesombongan, tapi rasa bangga karena bersyukur kita semua bisa menjadi santri di Misbah, semua merupakan kasih sayang Alloh SWT, tinggal bagaimana kita menjalani santri dengan benar" (Hasil wawancara dengan informan santri Muhammad Badri Tamam, tanggal 2 februari 2017)

\section{Konsep Diri Ustad Pondok Pesantren Salafiyah Misbahulkhoir}

Ustad di pontren Misbahulkhoir juga tidak dianggap sebagai gelar yang otomatis disandang oleh santri yang seiring dengan lamanya santri mukim, meskipun lama mukim menjadi salah satu kriteria yang ditentukan oleh Kang Haji.

Sebutan ustad di pontren berasal dari diri di luar ustad tersebut, terutama berasal dari para santri. Sebutan ustad dari para santri merupakan sebagai konsekuensi dari tugas yang diberikan oleh Kang Haji, karena sosok "ustad" dipandangan para ustad di Misbahulkhoir merupakan sosok pribadi yang membutuhkan kualifikasi dan standarisasi dalam hal keagamaan.

"Abdi mah teu ngarumaoskeun janten ustad, kumargi nu disebat ustad teh kedah jalmi anu leureusleureus ngagaduhan elmu agama sareng pangarti nu luhung. Malihan mah aya katerangan yen hiji jalmi nu disebat ustad teh kedah apal kana Al-Quran sareng gaduh rebuan hapalan Hadis. Rupina sebatan ustad kanggo abdi di dieu mah, mung saukur sebatan wungkul kumargi abdi ditugaskeun ku Kang Haji kanggo ngaping santri. Da saleureusna mah abdi ge di dieu teh santri keneh nu masih nyuprih elmu ka Kang Haji.Mmung mudah-mudahan we atuh, Kang, tugas ti Kang Haji teh janten mangrupikeun doa."

"Saya tidak merasa diri menjadi ustad, karena yang disebut ustad itu haruslah orang yang betulbetul memilki ilmu agama dan pengetahuan yang tinggi. Bahkan ada keterangan yang menyatakan bahwa yang disebut ustad itu harus hapal Al-Quran dan hapal ribuan Hadist. Sepertinya sebutan ustad terhadap saya disini hanya sebatas sebutan saja dikarenakan saya ditugaskan Kang Haji untuk membimbing santri. Sebetulnya saya disini juga masihlah seorang santri yang menimba ilmu ke Kang Haji, mudah-mudahan tugas dari Kang Haji itu jadi merupakan doa ." (Hasil wawancara dengan Informan Ustad Ali Nurdin, tanggal 13 februari 2017)

Ustad menjalankan perannya sebagai guru atau tenaga pengajar-pendidik yang mentransformasikan ilmu pengetahuan serta menjadi orang yang pertama tahu dan berusaha menyelesaikan permasalahan yang dihadapi oleh para santri baik didalam maupun di luar pondok. Ustad memandang konsep dirinya sebagai buah dari interaksi yang dilakukan dengan santrinya dan berdasarkan pengalaman diri ustad ketika berada dalam posisi santri di Misbahulkhoir. Interaksi dan pengalaman itulah yang menghasilkan harapan-harapan pihak lain, dalam hal ini santri, yang membentuk konsep diri ustad di pondok.

\section{Konsep Diri K.H. Asep Buldanularifin sebagai Kyai}

"Janten kieu, eta gelar teh aya nu disebat Ustad, Kyai, Ulama, Ajengan, malihan di Jawa mah (Jawa Tengah atau Jawa Timur) langkung lemes disebatna teh Romo Yai. Mung hapunteun ti babaheula oge Akang mah sanes Ustad, sanes Ajengan. Akang mah hiji jalmi nu nuju nyiarkeun Islam nu nuju diajar lelengkah halu hoyong ngabina umat sasuai sareng kamampuhan, hoyong ngamalkeun elmu anu saluyu anu mangpaat kanggo kamaslahatan umat. Numawi, hapunteun, ah bade nyebat paripaosna Amang, mangga, bade nyebat Akang, mangga." 
"Jadi begini, gelar itu ada yang disebut Ustad, Kyai, Ulama, Ajengan, bahkan di Jawa (Jawa Tengah atau Jawa Timur) lebih halus menyebutnya dengan Romo Yai. Tapi, maaf dari dahulu pun Akang itu bukan Ustad, bukan pula Ajengan. Akang itu seorang manusia yang sedang mendakwahkan Islam, yang sedang belajar melangkah dalam membina umat sesuai dengan kemampuan sendiri, berkeinginan untuk mengamalkan ilmu yang sejalan dan bermanfaat untuk kemaslahatan umat. Sehingga, maaf, mau memanggil dengan sebutan Amang (sebutan umum Sunda untuk orang yang lebih tua) pun silahkan, mau memanggil Akang juga tidak masalah." (Hasil wawancara dengan Key Informan K.H. Asep Buldanularifin, tanggal 20 februari 2017)

Kang Haji meng-konsepkan dirinya sebagai seseorang dengan standar fungsi dan peran sebagai manusia yang memberikan manfaat dan kemaslahatan bagi umat, tanpa membebankan diri dengan sebutan Kyai. Bagi Kang Haji sosok kyai merupakan seseorang yang sudah mencapai tahapan ilmu dan pelaksanaannya yang paripurna.

\begin{abstract}
"Akang teu nyebatkeun diri Kyai, kumargi Akang teh rumaos isin teu acan dugi kana waktosna pami kedah disebat Kyai mah. Bujeung-bujeung kana Kyai kana Ustad atanapi Ulama oge Akang mah teu acan dugi kana $U$ na oge. Ku disebat Akang oge Alhamdulillah eta mangrupikeun kabanggaan kanggo Akang mah. Janten eta gelar teh moal tiasa diraih ku cara jalmi, teu aya sakolna, anging Alloh nu masihan eta gelar.
\end{abstract}

"Seterusnya, kenapa Akang tidak pernah menyebut diri Akang sebagai seorang Kyai, karena Akang merasa malu karena belum sampai pada waktunya untuk disebut Kyai. Jangankan untuk disebut Kyai, disebut Ustad ataupun Ulama pun, Akang belum sampai meskipun pada "huruf U” nya saja. Dengan disebut Akang saja Alhamdulillah itu sudah merupakan kebanggaan untuk Akang. Jadi gelar tersebut tidak akan pernah bisa diraih dengan cara manusia, tidak ada sekolahnya, hanya Alloh SWT lah yang bisa memberikan gelar tersebut." (Hasil wawancara dengan Key Informan K.H. Asep Buldanularifin, tanggal 2 februari 2017)

Dalam konsep diri Kang Haji di satu sisi tidak terdapatnya penolakan diri terhadap penghormatan orang lain dan di sisi lain pemenuhan terhadap apa yang diharapkan orang lain akan dirinya dijalani dengan menjadi seseorang yang berkontribusi dalam pendidikan dengan melestarikan budaya salafiyah di pondok pesantren Misbahulkhoir. Kang Haji mengambil peran sebagai sosok yang mengkomunikasikan dan mengimplementasikan visi secara baik dan tepat; serta menciptakan komitmen terhadap nilai-nilai pesantren dan budaya pesantren.

\title{
Pemaknaan Santri, Ustad, dan Kyai terhadap Objek Simbolik
}

Pemaknaan Santri, Ustad, dan Kyai terhadap objek-objek simbolik di pondok pesantren salafiyah Misbahulkhoir terbagi dalam dua sesuai dengan konstruksi dari simbol itu sendiri.

Pemaknaan Terhadap Objek Simbol Fisik

Objek-objek fisik yang dimaknai oleh warga pondok ini diartikan sebagai struktur fisik yang hadir dalam proses interaksi sosial yang dimaknai dengan atau tanpa kehadiran struktur fisik tersebut, juga dengan atau tanpa kehadiran orang lain, antara lain: gapura dan akses jalan menuju pondok, masjid, kobong atau pondokan santri, rumah dan ruang tamu Kang Haji, Kaligrafi, Kitab Kuning, pakaian dan aksesoris.

1) Gapura dan akses jalan menuju pondok. Penempatan gapura pesantren disandingkan dengan papan nama Nahdatul Ulama dimaksudkan sebagai sebuah pernyataan bahwa pondok pesantren Misbakhulkhoir merupakan bagian utuh dari Nahdatul Ulama, yakni organisasi ulama yang pada umumnya berasal dan berakar dari salafiyah. Penempatan gapura tersebut dimaksudkan untuk hal sebagai berikut; pertama, mempertegas pontren Misbahulkhoir sebagai pondok pesantren yang benar-benar menjungjung tinggi salafiyah. Kedua, pontren Misbahulkhoir sebagai lembaga pendidikan yang memelihara nilai-nilai luhur para ulama terdahulu. Ketiga, pontren Misbahulkhoir merupakan bagian dari Ahlu Sunnah wal Jamaah.

2) Ketiga maksud tersebut merupakan sebuah pernyataan simbolik dari pontren Misbahulkhoir yang ditujukan dan dengan mudah dimaknai oleh orang yang melihat gapura pesantren, dan 
pemaknaan orang ini sesuai dengan maksud dan tujuan yang diharapkan oleh pondok pesantren Misbahulkhoir, sehingga terjadi pemaknaan bersama (shared meaning). Pemaknaan terhadap pernyataan simbolik tersebut menyatakan bahwa pondok pesantren Misbahulkhoir adalah salafiyah dan merupakan bagian dari Nahdatul Ulama yang merupakan organisasi Ahlu Sunnah wal Jamaah.

3) Masjid. Masjid Misbah untuk pondok pesantren Misbahulkhoir mempunyai fungsi dan makna yang lebih dari sekedar tempat berlangsungnya ritual ibadah ataupun terbatas sampai sarana pembelajaran. Untuk Kang Haji Asep sendiri, masjid Misbah lebih bermakna emotional-historic, karena Kang Haji Asep memandang Masjid Misbah sebagai representasi dan sarana pengingat akan syiar dan perjuangannya dalam membangun dan mengembangkan pendidikan Islam bercorak salafiyah. Kang Haji memandang masjid Misbah sebagai buah dari hasil perjuangannya dalam syiar Islam lewat media pendidikan sekaligus pengingat untuk selalu tetap istiqomah (konsisten) dalam menjalankan proses pendidikan di pondok pesantren dengan menciptakan kader santri yang nantinya mempunyai sikap dan sifat istiqomah juga.

4) Rumah dan ruang tamu Kang Haji. Penataan bangunan ruang tamu dan rumah Kang Haji dari sisi eksterior dan interior juga dari cara menerima tamu Kang Haji yang tidak memandang latar belakang tamu menggambarkan nilai-nilai kesetaraan, persaudaraan berdasarkan semangat silaturahim, dan nilai keadilan yang dikembangkan di pondok pesantren Misbahulkhoir.

5) Kaligrafi. Kaligrafi mempertegas makna lingkungan salafiyah yang memiliki tata nilai yang sesuai dengan apa yang dipesankan dalam kaligrafi tersebut dari sisi keberadaannya, misalnya kaligrafi "Al-Ulama Wa Ratsatul Anbiya". Sedangkan dari sisi muatan pesannya sendiri, kaligrafi sebagai motivasi dan pengingat bagi setiap warga pondok untuk selalu memberikan manfaat dalam hidup, misalnya kaligrafi "Khoirunnas Anfauhum Linnas".

6) Kitab Kuning. Pertama, kitab kuning memawakili atau sebagai simbol salafiyah itu sendiri. Kitab kuning sebagai bentuk sinkronisasi pembelajaran antara bahan dan sumber ajar, metode, dengan nilai ke-dahulu-an salafiyah, dimana kitab kuning ditulis dan disusun oleh ulama-ulama terdahulu yang kredibilitasnya terpercaya. Secara sederhana, pemaknaan tersebut mengandung arti tidak akan ada salafiyah dan pondoknya tanpa keberadaan kitab kuning, sehingga konsekuensi dari suatu lembaga yang menganut ajaran Salafiyah mengharuskan untuk manjadikan kitab kuning sebagai jiwa dalam penyenlenggaraan pendidikannya. Kedua, keharusan untuk menguasi ilmu tertentu sebelum menguasi cara membaca dan memperdalam kitab kuning, seperti nahu sharaf dimaknai sebagai sebuah usaha (ikhtiar) dari para santri untuk menguasai ilmu dengan penuh niat, kedisiplinan, dan pengorbanan. Ilmu tidak akan pernah didapatkan dengan cara yang mudah (rosishin dan tafakuhfidin). Penguasaan ilmu-ilmu tertentu sebelum membaca kitab kuning bukan berarti sebagai hambatan dalam belajar atau mempersulit para santri untuk mempelajarinya, akan tetapi sebagai salah satu usaha untuk menjaga kemurnian dari kitab kuning itu sendiri. Ketiga, kitab kuning mewakili sosok para ulama terdahulu sebagai penulis dan penyusun, sehingga kitab kuning sebagai simbol keberkahan sumber ilmu, ilmu, dan yang menyampaikan ilmu tersebut.

7) Pakaian dan Aksesoris. Pakaian dan aksesoris yang dipakai warga pontren terutama terdiri dari sarung, kopiah, dan sorban. Pemaknaan terhadap tiga objek simbol tersebut tidak terbatas pada tata aturan agama dan fungsi, tetapi juga bermuatan makna historis pengidentitasan santri juga pemaknaan nilai-nilai ke-Ilahian.

\section{Pemaknaan Terhadap Objek Simbolik Non Fisik}

Objek non fisik sebagai abstraksi objek dari prinsip moral yang dianut, filosofi doktrin, atau nilainilai dari rasa keadilan dan kasih sayang. Objek non fisik sama halnya dengan objek fisik yang mengarahkan seseorang pada pemaknaan. Pemaknaan yang didalamnya terdapat cara pandang, cara bertindak, serta cara mengungkapkan objek tersebut, antara lain: Barokah Ilmu dan Barokah Kyai, Sami'na wa Ato'na dan Kualat, serta konsep Ngaliwet.

1) Barokah Ilmu dan Barokah Kyai. Keberkahan ilmu dan keberkahan dari seorang Kang Haji merupakan inti dari proses dan tujuan yang menjiwai nilai-nilai pendidikan pondok pesantren 
Misbahulkhoir, dimana Kang Haji sebagai seorang kyai merupakan simbolisme fisik yang bermakna dan berfungsi sebagai perantara untuk mendapatkan keberkahan-keberkahan tersebut. Simbolisme barokah ilmu dan Kyai ini dimaknai oleh para santri dan ustad dengan aplikasi tindakan sebagai berikut: bagaimana memperlakukan yang memberi ilmu, bagaimana memperlakukan tempat menimba ilmu, bagaimana memperlakukan kitab dan buku sebagai sebagai sumber ilmu, bagaimana menggunakan ilmu yang sedikit sehingga bermanfaat bagi orang banyak, dan bagaimana menjadikan ilmu sebagai sarana dalam menjaga tali silaturahim.

2) Sami'na wa Ato'na dan Kualat. Pertama, kebarokahan ilmu, diri, dan kehidupan didapatkan dengan memaknai sami'na wa ato'na melalui tindakan yang diridhoi oleh kyai. Kedua, antitesa dari sami'na wa ato'na adalah kualat. Santri Misbahulkhoir mengganggap kualat sebagai suatu kondisi dimana para santri tidak mendapatkan kebaikan yang diperoleh dari doa dan barokah Kang Haji. Bagi para santri, kualat bukan saja situasi dimana mereka dalam kondisi melawan, membantah, ataupun secara sikap menunjukan ketidak-berterimaan terhadap Kang Haji, namun lebih dari itu, kualat dipandang sebagai konsekuensi negatif terhadap kehidupan dimana mereka mulai ber-kualat sampai pada saat kebarokan dan keridhoan Kang Haji yang akan mengakhiri masa kualat tersebut.

3) Ngaliwet. Terdapatnya pemaknaan kesederhanaan (tawadlu), pengembangan kesadaran akan keberadaan alam sekitar, sikap selalu berikhtiar dalam kerja sama, pembelajaran efesiensi dan efektifitas pemenuhan kebutuhan, penghargaan diri terhadap hasil yang diusahakan, serta kesetaraan antar sesame santri.

\section{Tindakan Simbolik dalam Komunikasi Pendidikan}

Tindakan simbolik sebagai bagian dari komunikasi pendidikan di pondok pesantren salafiyah Misbahulkhoir. Tindakan simbolik santri merupakan hasil dari pemaknaan santri terhadap objekobjek simbolik yang terdapat di pondok pesantren yang dinyatakan melalui cara memperlakukan objek simbolik atau pilihan tindakan yang diambil terhadap objek tersebut sesuai dengan asal pemaknaan terhadap objek tersebut, yaitu.

1) Tindakan simbolik santri mencium tangan Kang Haji dengan membolak-balikan tangannya. Mencium tangan kyai merupakan produk tindakan simbolik yang berasal dari konsep diri santri yang memandang dirinya sebagai seseorang yang membutuhkan sosok kyai untuk melengkapi konsep dirinya sebagai santri. Mencium tangan kyai sebagai simbol silaturahim fisik dan batin antara diri santri dengan kyai yang ditunjukan dengan cara mendalam. Mencium tangan kyai berarti mengambil barokah dari prosesi mencium tangan dengan membulakbalikannya, karena tangan yang mereka cium adalah tangan yang selama selalu mendoakan dan mengerjakan kebaikan.

2) Tindakan simbolik santri membersihkan rumah Kang Haji. Kang Haji sebagai pihak empunya rumah, menyadari makna edukasi dari membersihkan rumahnya meskipun Kang Haji sendiri tidak pernah mempermasalahkan terhadap proses akhir dari tindakan ini. Kang Haji lebih menilai tindakan ini sebagai pembiasaan para santri, seperti halnya ketika Kang Haji masih menimba ilmu di pondok lain, yang merasakan manfaat dari pembiasaan ini. Makna kemanfaatan dari tindakan simbolik membersihkan rumah ini, tidak pernah diungkapkan oleh Kang Haji kepada santrinya. Pesan disampaikan melalui pengkondisan pembiasaan tersebut.

3) Sikap simbolik santri menundukan kepala. Sikap menundukan kepala sebagai implementasi dari rasa malu santri ketika berhadapan langsung dengan Kang Haji, sehingga para santri hanya memandang Kang Haji sebatas dada, sedangkan ketika berhadapan dengan Teh Haji, pandangan santri diarahkan ke kedua kakinya sendiri. Santri berusaha menjaga tata kesopanan diri yang didasari oleh rasa malu dan perasaan takut ada yang salah dalam perkataan dan perbuatan. Menunduk pertanda keseriusan diri dalam menyerap setiap informasi keilmuaan dan konsentrasi diri dalam menyerap materi. Menunduk bermakna melepaskan pandangan dunia dengan memfokuskan diri ke tempat sujud ketika berada di Masjid sebelum melaksanakan sholat berjamaah yang biasanya disertai dengan bacaan-bacaan sholawat ataupun zikir. 
4) Perlakuan terhadap kitab kuning dan buku umum. Kebarokahan ilmu didapatkan oleh para santri salah satunya tergantung pada bagaimana cara santri tersebut memperlakukan kitab atau buku dengan isinya. Penyimpanan kitab dan buku dilakukan sebaik mungkin penuh dengan rasa penghormatan dan tidak diperbolehkan kitab dan buku tersebut tertumpuk oleh bendabenda yang lainnya, sehingga harus selalu ditempatkan pada posisi atas.

5) Tindakan simbolik Kang Haji mengusap kepala santri. Para santri memaknai usapan dari Kang Haji ini sebagai rasa kasih sayang guru terhadap muridnya yang dipenuhi dengan harapan agar para santri menjadi santri yang berbakti terhadap guru dan pondoknya.

\section{Pemakanaan bersama (shared meaning)}

Tindakan simbolik dalam komunikasi pendidikan yang dilakukan di luar kesengajaan (kesadaran), sesungguhnya merupakan hasil pendidikan dalam kesadararmya, karena ketidak sengajaan dalam suatu tindakan akan dipengaruhi oleh pengalaman yang disengaja. Pengalaman yang diperoleh dalam kesengajaan (kesadaran) seseorang akan mengendap menjadi ketidak sadaran. Dan pengalaman yang disengaja atau pengalaman sadar itu suka muncul dalam tindakan yang tidak disengaja atau tidak disadari. Oleh karena itu ketidak sengajaan atau ketidak sadaran dalam suatu tindakan itu akan muncul sebagai suatu tindakan positif manakala pengalaman yang disengajaannya atau disadarnya positif. Suatu tindakan di luar kesadaran dapat muncul karena kebiasaan, kebiasaan akan muncul dari pengkondisian, dan pengkondisian itu dilakukan dalam suatu tindakan yang disadari, sedangkan tindakan yang disadari lahir dari pengalamannya.

\section{SIMPULAN}

Pondok pesantren salafiyah Misbahulkhoir merupakan lembaga pendidikan non-formal yang menyelenggarakan proses pendidikan berbasis agama dan tradisi, dengan nilai-nilai pendidikan tradisi sunda dan salafi. Nilai-nilai pendidikan tersebut dimaknai secara Interaksi Simbolik sebagai berikut: Mempertahankan unsur-unsur pendidikan; bahan ajar, proses kegiatan belajar mengajar, konsep dan tata letak sarana dan prasana belajar, dan rekrutmen peserta didik dan tenaga pendidik, yang berdasar pada ketradisionalan (salafiyah) pola pendidikan ulama-ulama terdahulu. Kitab Kuning sebagai simbol utama dari pendidikan yang bermakna kumpulan materi ajar yang ditulis dan disusun oleh ulama-ulama terdahulu, sehingga cara penyampaian materi sebagai sebuah pesan pendidikan pun dilakukan dalam proses dan teknik belajar mengajar sesuai dengan tuntutan salaf, yakni dilakukan dengan bandongan ataupun sorogan. Kyai mengambil peran dalam komunikasi pendidikan sebagai komunikator utama dimana pesan yang disampaikan olehnya dimaknai oleh para santri dan ustad sesuai dengan konsep diri dan tata nilai lingkungan pondok pesantren. Pola pendidikan salafiyah merupakan pola pendidikan yang terintegrasi secara untuh sebagai objekobjek simbolik yang terdapat pada lingkungan fisik dan lingkungan non fisik di dalam pondok. Pola pendidikan salafiyah berdasar simbol disikapi oleh warga pondok pesantren dengan tindakantindakan simbolik dimana pemaknaan terhadap berbagai simbol tersebut merupakan hakekat yang sebenarnya dari pendidikan pesantren salafiyah.

Konsep diri yang terbentuk dan dibentuk warga pondok pesantren salafiyah Misbahulkhoir memunculkan identitas dan karakteristik tersendiri sebagai pola komunikasi pendidikan yang unik yang membedakan antara pola komunikasi pendidikan di lembaga pendidikan umum maupun lembaga pendidikan yang bercorak salafiyah lainnya.

Pemaknaan Santri, Ustad, dan Kyai terhadap objek-objek simbolik di pondok pesantren salafiyah Misbahulkhoir terbagi dalam dua sesuai dengan konstruksi dari simbol itu sendiri, yakni: pemaknaan terhadap objek simbol fisik dan non fisik.

Tindakan simbolik sebagai bagian dari komunikasi pendidikan di pondok pesantren salafiyah Misbahulkhoir. Tindakan simbolik santri merupakan hasil dari pemaknaan santri terhadap objekobjek simbolik yang terdapat di pondok pesantren yang dinyatakan melalui cara memperlakukan objek simbolik atau pilihan tindakan yang diambil terhadap objek tersebut sesuai dengan asal pemaknaan terhadap objek tersebut. 
Pemakanaan bersama (shared meaning) antara santri, ustad, dan kyai terhadap simbol-simbol komunikasi pendidikan di pondok pesantren salafiyah Misbahulkhoir. Tindakan simbolik dalam komunikasi pendidikan yang dilakukan di luar kesengajaan (kesadaran), sesungguhnya merupakan hasil pendidikan dalam kesadararmya, karena ketidak sengajaan dalam suatu tindakan akan dipengaruhi oleh pengalaman yang disengaja.

\section{REFERENSI}

Abidin, Z. B. S. (2009). Buku Putih Dakwah Salafiyah. Jakarta: Pustaka Imam Abu Hanifah.

Bahri, M. G. (2001). Pendidikan Pesantren Berwawasan Lingkungan. Jakarta: Pedoman Ilmu.

Berger, A. A. (2000). Tanda-tanda dalam Kebudayaan Kontemporer. Yogyakarta: Tiara Wacana.

Devito, J. A. (1997). Human Communication. New York: Harper Collinc College Publisher.

Dhofier, Z. (2011). Tradisi Pesantren. Jakarta: LP3ES.

Elbadiansyah, U. (2014). Interaksionosme Simbolik Dari Era Klasik Hingga Modern. Jakarta: Raja Grafindo Persada.

Horikoshi, H. (1987). Kyai dan Perubahan Sosial. Jakarta: P3M.

Kuswarno, E. (2009). Fenomenologi. Bandung: Widya Padjadjaran.

Littlejohn, S. W. (1996). Theories of Human Communication (Edisi 5). Belmont California: Wadsworth. Madjid, N. (1997). Bilik-Bilik Pesantren: Sebuah Potret Perjalanan. Jakarta: Paramadina.

Mastuhu. (1994). Dinamika Sistem Pendidikan Pesantren. Jakarta: INIS.

Moleong, L. J. (2010). Metodologi Penelitian Kualitatif (edisi revisi). Bandung: Remaja Rosdakarya.

Moesa, A. M. (1999). Kiai dan Politik dalam wacana Civil Society. Surabaya: LEPKISS.

Mulyana, D., \& Solatun. (2007). Metode Penelitian Komunikasi Contoh Contoh Penelitian Kualitatif Dengan Pendekatan Praktis. Bandung: Remaja Rosdakarya.

Wahid, A. (1995). Bunga Rampai Pesantren. Jakarta: Dharma Bakti. 